\title{
ENVIRONMENTAL POLICY PERFORMANCE REVISITED: \\ DESIGNING EFFECTIVE POLICIES FOR GREEN MARKETS
}

\section{Pre-print version (17 November 2010). Final version is forthcoming in Political Studies}

\author{
Carsten Daugbjerg (corresponding author) \\ Professor \\ Department of Political Science \\ Aarhus University \\ Bartholins Allé 7 \\ DK-8000 Aarhus C \\ Denmark \\ $\&$ \\ Research School of Social Sciences, \\ The Australian National University \\ E-mail: $\underline{\text { cd@ps.au.dk }}$
}

and

\author{
Kim Mannemar Sønderskov \\ Assistant professor \\ Department of Political Science \\ Aarhus University \\ Bartholins Allé 7 \\ DK-8000 Aarhus C \\ Denmark
}

E-mail: ks@ps.au.dk 
ENVIRONMENTAL POLICY PERFORMANCE REVISITED:

DESIGNING EFFECTIVE POLICIES FOR GREEN MARKETS

\begin{abstract}
Studies of environmental policy performance tend to concentrate on the impact of particular policy institutions or of single policy instruments. However, environmental policies most often consist of a package of policy instruments. Further, these studies pay no or very little attention to policy instruments directed at the demand-side of the market. Therefore this article develops a policy typology for government intervention aimed at creating green markets. The typology distinguishes between four types of policies based on the balance between supply-side and demand-side policy instruments applied. On the basis of the typology, a hypothesis on their ability to expand green markets is generated and tested in a comparative analysis of the performance of organic food policies in Denmark, Sweden, the UK and the US, focusing on their impact on organic consumption. Our analysis demonstrates that cross-country variation in organic food consumption is explained by differences in the packages of policy instruments applied, controlling for numerous systemic and individual level alternative explanations. The analysis suggests that for environmental and political reasons, governments should apply more demand-side instruments when introducing environmental policies.
\end{abstract}




\section{INTRODUCTION}

'What the cynics fail to understand is that the ground has shifted beneath them - that the stale political arguments that have consumed us for so long no longer apply. The question we ask today is not whether our government is too big or too small, but whether it works'.

This statement in President Obama's inaugural speech on 20 January 2009 was an encouragement for policy analysts throughout the world and signalled an end to policy making based on the dogma 'government is not the solution ...; government is the problem' as stated by President Reagan in his inaugural speech in 1981. But how do we know what works and what does not? Though this question may seem trivial, making public policies deliver what they promise is a formidable task (Pressman and Wildavsky, 1983; Howlett, 2009), and policy failure is just as likely as policy success (Vogel, 2003).

What works and what does not is a key concern in environmental policy and there is now a substantial literature on environmental policy performance analysing the impacts of environmental policies. This literature has demonstrated useful methods to establish whether or not - or rather to what extent - environmental policies work. However, the literature still suffers from various shortcomings. Some studies focus on institutions as the key factor influencing environmental performance. For instance, Scruggs (2003), Crepaz (1995), and Jahn (1998) analyse the impact of corporatism on environmental performance, and they find a positive correlation between corporatism and environmental performance. Using not dissimilar concepts, Jänicke (1992) also applies an institutional approach to environmental policy performance. However, in these studies it remains unspecified how a high degree of corporatism produces particular policy choices which in turn lead to better environmental performance.

Other studies deal with the effectiveness of various environmental policy instruments and therefore address policy content which is insufficiently dealt with in the institutional approach. As it was realized in the late 1980s and 1990s that command-and-control policies did not meet the expectations in terms of their ability to bring about environmental improvement, governments experimented with new market based environmental policy instruments. The instrument focused 
research strategy assesses the effectiveness of these instruments, often focusing on a single policy instrument. For instance Andersen (1994) concentrates on the environmental performance of environmental charges, Enevoldsen (2005) focuses on the performance of voluntary environmental agreements compared with that of emission charges, and Svendsen (1998) analyses the cost-effectiveness of tradable pollution permits compared with emission charges. However, this focus on single instruments pays insufficient attention to the fact that most public policies are composed of a combination of several policy instruments, and consequently performance most often results from a package of instruments rather than a single instrument (Lascoumes and Le Gales, 2007, p. 5; Howlett, 2005, p. 42; Vedung, 1998, p. 39). Further, perhaps reflecting the fact that most environmental regulation of industries addresses the supply-side of the market, these studies pay no or very little attention to the demand-side.

The reasoning behind the market based supply-side policy instruments is to increase environmentally sustainable production by creating economic incentives for producers to shift to cleaner production technologies. It is assumed that industries' cost of implementing the instruments can be retrieved through efficiency gains and/or through growing demand for green produce in the market. Though increasing demand is seen as an important driving force in bringing about environmentally sustainable markets (Carter, 2007, p. 232), the policy effort tends to be directed at the supply-side. Therefore this article directs analytical attention to instruments aimed at generating increasing demand and analyses how they are, and can be, combined with supplyside instruments.

Recent research on policy instruments has emphasised the need to 'understand the complexity of multiple instrument mixes' (Howlett, 2005, p. 49). Thus, rather than focusing on specific instruments, analysts should focus on the performance of combinations of policy instruments directed at both the supply-side and the demand-side of the market. In this article we develop a policy typology that is able to describe the various combinations of instruments used in environmental policy. Efforts to develop policy typologies have been limited, in particular in relation to the development of generic policy typologies. Lowi's (1972) typology of public policies remains the key reference more than four decades after it was published. This indicates that there 
has been very little progress, especially considering that Lowi's typology has been strongly critiqued for not clearly defining the categories and for outlining policy types that are not mutually exclusive (Wilson, 1973). The lack of progress in efforts to develop generic policy typologies is striking and may indicate that there is too much variation across policy fields to allow scholars to develop all-encompassing policy typologies which, at the same time, are meaningful and parsimonious. The development of policy typologies for specific policy fields is a more promising research strategy, and one we will be following in this article. Although the development of policy typologies may in itself have value, the ultimate test of a typology's utility is its ability to facilitate knowledge generation. A typology must be able to pinpoint the key differences in policies which potentially can explain or predict variation in outcomes. In other words, a policy typology must facilitate generation of hypotheses on the relationship between policy types and policy effects.

The next section develops a typology for government intervention aimed at promoting green markets and formulates a hypothesis on the relationship between policy types and policy effect. The empirical section tests the hypothesis in a comparative analysis of the relationship between organic food policies and organic consumption in Denmark, Sweden, the United Kingdom and the United States. Organic farming provides environmental benefits through the non-use of pesticides and less intensive farming methods. In many countries this has legitimised government intervention into the sector. To support the promotion of the organic food sector, governments have introduced various combinations of supply-side and demand-side policies with varying impacts. We start the analysis by categorizing the organic food policies of the four countries, using the typology. On the basis of consumption data from several sources as well as individual level survey data from a cross-national, tailor-made survey, it is then established whether consumption levels fit the hypothesis, controlling for alternate institutional, structural and individual level explanations. The final section discusses the implications for future analyses of policy performance as well as the utility of the typology.

\section{POLICY TYPES AND POLICY EFFECTS}


The Tinbergen theorem suggests that only one instrument should be introduced for each target and that targets should be directly, rather than indirectly, addressed (Tinbergen, 1952, p. 27; Oikonomou, Flamos and Grafakos, 2010, p. 4187; Ergas, 2010, p. 149). ${ }^{1}$ The theorem is based on the assumption that public policy making is a rational process in which the first stage is to agree on values and formulate clear objectives followed by a stage in which the optimal mix of policy instruments is adapted. However, the policy process rarely operates that neatly. Firstly, as Lindblom $(1958$, pp. 535, 538) points out, critiquing Tinbergen's work, 'the means-end dichotomy ... is deficient because it denies obvious conflicts of ends, fails to take account of the fact that what is an end to one group is a means to another' and that in politics, 'the choice of welfare functions is hardly more than a detail', and 'there is no "correct" or "incorrect" alternative'. Secondly, the problem targeted by policy can be complex and multi-facetted and cannot always be addressed directly. Therefore, they can only be solved by affecting a number of aspects of the problem at the same time and often in an indirect way (Gunningham et al., 1998; OECD 2007, pp. 21-22). A high level of complexity often implies that there is uncertainty on stimulus-effect relationships and engaging in policy experiments may be the only way to generate knowledge on these relationships (Lindblom, 1958, p. 532; Gunningham et al., 1998, pp. 395-96). Rather than adopting a single instrument, policy makers can successfully address a multi-facetted problem by applying multiple instruments aimed. Individual instruments have strengths and weaknesses in relation to specific, complex policy problems (Gunningham et al., 1998, pp. 38-91) and therefore 'the best means of overcoming the deficiencies of individual instruments, while taking advantage their strengths, is through the design of combinations of instruments ... [I]t is crucial ... to design a complementary mix of instruments designed to specific policy goals' (Gunningham et al., 1998, p. 388), and avoid counterproductive interactions between the instruments (Gunningham et al., 1998, pp. 126-31).

The way policy instruments are combined defines policy. Different policies are likely to produce different outcomes. While there is a substantial literature focusing on the factors influencing particular policy instruments choices, such as state capacity and target complexity (Howlett, 2005), policy styles (Howlett, 2009, pp. 75-78), party politics and moral issues (Hood, 1983, pp. 132-41) and institutional settings (Linder and Peters, 1989), research on the effectiveness of instrument

\footnotetext{
${ }^{1}$ However, Tinbergen (1952, p. 37) does not rule out that in atypical situations more than one instrument can be applied for each target.
} 
mixes is relatively limited (Eliadis, Hill and Howlett, 2005, p. 8; Oikonomou, Flamos and Grafakos 2010, p. 4186). Research on policy instruments has devoted considerable effort to the development of policy instrument typologies, but an authoritative instrument typology has not yet been developed (see Hood 2007 for a review of the policy instrument literature. See also Hood, 1983; Howlett, 2005, 2009; Vedung, 1998, Lascoumes and Le Gales, 2007 for different examples of instrument typologies). Within the field of environmental policy, typologies for environmental policy instruments have been developed (e.g. Gunningham et al., 1998, pp. 38-91; Jordan et al., 2005, pp. 482-83). Here we apply Hood's classic distinction between governing resources based upon information (informative instruments), authority (regulatory instruments), treasure (economic instruments) and organization (Hood, 1983). This distinction between instruments based upon differences in the motivational rationales of the instruments, that is, information, rules, incentive and 'architecture' respectively, has proved quite robust since it underpins many instrument typologies (Hood, 2007, p. 141)

These instruments can be applied on the supply-side and the demand side in various combinations, and it is this combination that defines policy. To depict the distinctiveness of various instrument combinations, we develop a policy typology. Four basic types of instrument combinations can be identified (Table 1). The two dimensions in Table 1 are to be considered continuous scales; therefore the four types of policies outlined must be considered ideal types. Actual policies may not necessarily be clear-cut examples of one of the four types.

Table 1 about here

We expect the four mixes of policy instruments, i.e. the four policy types, to produce different outcomes. As the critical indicator of policy performance in government induced green market transformation we use consumption levels. Since establishing and increasing green markets is a multi-facetted exercise in which government policy must manipulate a number of factors in the market to achieve a successful outcome, the introduction of a package of policy instruments aimed both at the supply-side and at the demand-side of the market is likely to be the most effective policy type. However, this hypothesis can only be verified through empirical analysis. 
In the passive market development policy type (type I) government engagement is at a modest level. The main purpose of intervention is to provide the institutional infrastructure for the market to function. This involves some government engagement on the supply-side which in its basic form involves the use of regulatory instruments to set the baseline environmental production standards and perhaps the use of organizational instruments to establish or license credible eco-labelling schemes. Since the start-up costs for a new industry and the cost of converting from old to new production technology may be considerable, modest producer subsidies may be provided by the government to motivate producers to supply the new product to meet demand, but the state does not actively attempt to increase the market. The limited intensity with which government intervenes is likely to lead only to limited policy impact on consumption.

In the supply driven policy type (type II) governments tend to view the introduction of environmentally friendly products as a public good in its own right. To increase supply, the government will apply all four types of supply-side instruments to disseminate knowledge on green production methods, set baseline environmental production standards, establish research institutions and provide economic incentives, by the use of subsidies or environmental charges, to motive a switch to environmentally friendly production methods. These measures may be combined with limited demand-side measures such as licensing of eco-labelling schemes. Where this type of policy is implemented supply is likely to increase, but since demand is not simultaneously manipulated the growth in demand is likely to be modest. The resulting decline in prices may increase consumption to some extent, but unless production is maintained by generous producer subsidies, it is likely to decrease. Thus, since this policy type only aims at manipulating the supply-side of the market, the policy effect on consumption is likely to be modest.

The underlying philosophy of the demand creating policy type (type III) is that when demand is there, supply will grow. The policy instruments applied in this type are strongly focused on creating incentives for increased demand either directly or indirectly. Less interventionist strategies includes government sponsored information and marketing campaigns (informative instruments) and the establishment of eco-labelling schemes (organization). Supply-side 
instruments are limited to setting baseline environmental production standards (organization). Where government commits itself to implement powerful direct demand-side instruments, such as generous consumer subsidies (economic instruments) or compulsory purchasing (regulatory instruments), the policy impact on demand may be considerable and supply may increase correspondently, but not necessarily. The conversion costs may be prohibitive for some producers and therefore supply increases may be unable to match demand. Similar problems may emerge where less powerful demand-side instruments, such as state sanctioned voluntary eco-labelling schemes, are applied. Thus since demand creating policy also focuses on manipulating only one side of the market, the policy impact on consumption is likely to be modest.

In the active market development policy type (type IV) government commits itself to promote the greening of an industry through the introduction of a broad selection of all types of supply-side and demand-side policy instruments in order to stimulate fast market development. The simultaneous use of supply-side and demand-side policy instruments is intended to bring about positive interaction among the instruments. Policy-induced growth in supply lowers consumer prices, leading to increased consumption, but since demand-side instruments simultaneously increase demand, prices are maintained at levels sufficient to convince producers that the emerging green market is economically viable. This motivates them to increase supply. Though this growth of supply may only be partially matched by policy-induced rise of the demand, the greater market size enables economics of scale to be realized, maintaining profitability. Therefore active market development policies are likely to produce a relatively high level of consumption.

Table 2 sums up the preceding discussion and suggests an inventory of policy instruments most likely to be applied in the four policy types. It does not suggest a particular mix of instruments for each type; rather it lists the various policy instruments which may potentially form part of the instrument package.

Table 2 about here 
To summarize the theoretical considerations above we hypothesize that, all else being equal, (i) countries applying the active market development policy type will have the highest levels of consumption, (ii) countries applying supply driven and demand creating policy types will have medium levels of consumption, and (iii) countries applying the passive market development will have the lowest levels of consumption.

\section{RESEARCH DESIGN}

The hypothesis is tested by comparing the level of organic food consumption in Denmark, Sweden, the United Kingdom and the United States. The four countries, which are all post-industrial and modern liberal democracies, were selected to create variance in the independent variable as they apply three of the four policy types outlined above. This enables us to test whether policy variance produce different levels of consumption of organic food, controlling for a number other factors which can potentially explain variance in consumption. To our knowledge the demand creating policy type has not been applied in any country's organic food policy. ${ }^{2}$ As we shall see organic consumption varies across these countries. The purpose of the comparative analysis is to establish whether this variation can be put down to the differing policy packages applied, controlling for the consumption effect of a number of non-policy factors (alternate factors). The existing general literature on policy performance and the specific literature on organic food consumption identify several institutional and structural explanations as well as explanations referring to individual characteristics and attitudes which, rather than policy type, might explain variation in consumption. However efforts to apply a genuine comparative research strategy aimed at establishing the relationship between policy and growth of the organic sector are missing (see Daugbjerg and Halpin, 2008 for a review).

With alternate explanations at both the systemic and individual level, multilevel modelling would be the preferable analytical strategy. However, even if all countries with an organic food policy were included only a few degrees of freedom would be preserved due to the number of alternate

\footnotetext{
${ }^{2}$ Ideally, the analysis should cover all four types, but when applying typologies developed on the basis of deduction rather than induction, there is always a possibility that not all types are applied within a specific policy sector.
} 
system-level explanations. Therefore, we approach this multi-level challenge through a two-step analysis. First, to control for alternate explanations at the system level, the method of pattern matching is applied to establish whether the cross-national pattern of organic consumption conforms to the pattern that these alternate factors would suggest. If the theoretically derived pattern does not conform to the actual pattern, the alternate explanation can be ruled out (Yin, 2003). Second, a quantitative regression analysis is carried out to control for alternate explanations at the individual level, using data from a survey in the four countries designed and conducted specifically for this study.

In sum, our hypothesis would be supported if three conditions are met. The hypothesized relationship between policy type and consumption should be observed. Second, cross-national variation in systemic factors must be dismissed as explanations for different levels of consumption, and finally, it must be ruled out that the differences is caused by cross-national differences in citizens' attitudes, resources etc.

\section{CATEGORISING ORGANIC SECTOR POLICIES IN THE US, UK, SWEDEN AND DENMARK}

United States. The US is an example of a country applying a weak version of the passive market development policy type. The US organic food policy provides neither organic conversion nor permanent producer subsidies, but organic farmers are eligible for environmental subsidies under the Environmental Quality Incentives Program, introduced as part of the 2002 Farm Bill. However, the programme is aimed at conservation and reduction of pollution and is not specifically designed to promote organic farming (USDA/NRCS, 2008). The organic supply-side measures applied are indirect and are mainly state grants for research on organic production and marketing methods and for extension services (Johnson, 2008, 8-9). In 1990 the United States Department of Agriculture (USDA) was mandated by the Organic Foods Production Act to establish national minimum standards for organic produce, but it was not until 2002 that the USDA implemented such standards. The present US certification system relies on a state label (USDA organic), but certification and monitoring are undertaking by private certifiers who must be accredited by the 
USDA. The US government provides cost sharing subsidies for certification and accreditation (Johnson, 2008, pp. 7-9).

United Kingdom. A key feature of the British government's engagement with the organic sector is its continued insistence that state intervention should rest firmly on consumer demand and not on creating it. Therefore, the UK government has encouraged farmers to meet demand and has provided financial assistance to help them through the conversion years. In 1994 relatively modest conversion subsidies were introduced, and as a result of poor conversion rates a new conversion scheme with more generous conversion subsidies was introduced to motivate farmers to respond to growing demand. In 2003 permanent organic subsidies were introduced. Since 1991, the British government has funded research on organic production. The government has also made funds available for organic extension services from 1996 onwards. As to demand-side instruments, in 1987 the UK government delegated the authority to define government baseline organic standards and to monitor certification bodies to the UK Register of Organic Food Standards. In 2003 these executive functions were subsumed to the Department for the Environment, Food and Rural Affairs. The Soil Association is by far the most important certification body in the UK, certifying over 80 per cent of all organic food being sold in the UK (Daugbjerg et al., forthcoming). The British organic food policy can be characterized as a passive market development policy, but it comes in a more extended version than the US organic food policy because it actively attempts to stimulate supply when demand is identified. The conversion subsidies introduced in 1999 were quite generous, which indicates that the British policy shares one feature with the supply driven and active market development policy types.

Sweden. The Swedish organic food policy has had a strong focus on increasing the area farmed organically and therefore supply-side policy instruments have been dominant, strongly indicating that it is a supply driven policy. A conversion subsidy for organic farming was introduced in 1989 and in 1994 a modest permanent subsidy was introduced. As a consequence of Sweden's entry into the EU in 1995, relatively generous permanent subsidies for organic farming were introduced. 
Payments were differentiated according to region, crops grown and livestock kept. Payments were further differentiated in 1999 and increased, reaching comparatively high levels in particular for oil crops, potatoes, sugar beets, fruit and vegetables (Rydén, 2003, pp. 10-12, 22, 39). The state has provided increasing funding for research in organic production and has set up an extension service for organic farmers as part of the state agricultural advisory service. No significant support has been granted to demand oriented market development (Halpin et al., forthcoming). Organic certification and labelling are delegated to the private association KRAV, which was formed in 1985 and state accredited in 1993 (Boström, 2006, pp. 348-49). Organic farmers are not required to be KRAV certified to receive government subsidies for organic farming as long as they comply with EU rules on organic farming and are subject to inspection by the Board of Agriculture. However, KRAV certification is required to market produce as organic through commercial sales channels (Halpin et al., forthcoming).

Denmark. The Danish organic food policy is a clear cut case of the active market development policy. The Act on Organic Farming, adopted in 1987, introduced organic subsidies. Whilst the policy has been subject to a number of changes since then the basic structure of the policy has remained intact. A number of supply-side instruments have been applied. In 1987 conversion subsidies were introduced and in 1994 permanent organic subsidies were introduced. Up until 2004 conversion subsidies were differentiated to motivate particular types of farmers to convert to respond to market developments. Conversion subsidies to arable and pig farmers were generous and motivated to substantial overproduction of organic cereals in the early 2000 s but were unable to increase organic pig production. Partly as a consequence of this situation, a modest flat rate conversion subsidy was introduced in 2004. Considerable funding has been provided for research in organic farming since 1992 and organic extension services have been funded but more modestly. Considerable emphasis is put on demand-side policy instruments. State engagement in the Danish organic sector in the late 1980s entailed a shift from certification by a non-state body to a fully state operated certification and labelling system (the $\varnothing$-label). The state label is the sole national organic label and can only be applied by enterprises producing, processing or packaging organic produce in Denmark. The introduction of the state label meant that only state certified farms would be allowed to sell organically labelled products and receive 
state support. The state has provided considerable subsidies for market research, product innovation and marketing of organic produce. Funds allocated to these activities peaked at 97 million DKK in 2000 but was then reduced by almost 90 percent in 2005. Increased demand for organic food in 2006 renewed political interest in the sector and funding was increased in 2007 (Daugbjerg et al., forthcoming).

\section{ORGANIC FOOD CONSUMPTION IN THE US, UK, SWEDEN, AND DENMARK}

According to the hypotheses and the categorisation of the actual policies we would expect Denmark to have the highest level of consumption, while Sweden should be ranked second followed by the UK and the US which would be expected to have fairly similar consumption levels. Table 3 allows an initial test of this hypothesis; it contains measures of organic food consumption in the four countries from different points in time and from different sources. It is evident that the Danes consume far more organic food than the Swedes, Americans, and the British. Although the gap narrows over time, the Danes consume about twice as much as the others. The average figures indicate that Sweden outperforms the US and the UK, but the difference between Sweden and the US is smaller than expected. It is also surprising that the US has a higher level of consumption than the UK. However, roughly the empirical pattern corresponds to the theoretical expectations, but it is not a perfect match because we would have expected a larger difference between Sweden and the US and a lesser one between the US and the UK. This suggests that other explanations than policy type may be at play. To address this it is analysed whether other systemic and individual factors can explain the difference in consumption.

Table 3 about here

\section{Alternate explanations at the system level}


The literature on environmental performance and the more specialized literature on organics suggest various factors besides policy type as important driving forces behind environmental performance and organic consumption. As shown in Table 4 a number of alternative explanations for organic consumption can be ruled out.

Table 4 about here

Price premiums. Intuitively, consumption should be low where the additional price paid for organic products compared to conventional products is high (Hamm \& Gronefeld, 2004, p. 51). In Denmark, where consumption is highest we would expect low price premiums, but Danish consumers pay relatively high premiums, perhaps only surpassed by US residents. This observed pattern contradicts the expected and price premium size can therefore be ruled out. This finding corresponds with studies using more observations than here (Hamm \& Gronefeld, 2004, p. 125f; Sønderskov, 2009).

Sales channels. Where organic foods are mainly sold in supermarkets rather than health shops or at the farm gate, availability and thus consumption could be expected to be higher (Hamm \& Gronefeld, 2004, p. 125). However, this factor cannot explain the observed cross-country variation, as it would predict fairly similar levels of consumption in Sweden, Denmark and United Kingdom and a much lower level in the US, but the consumption data show that Sweden and the UK have much lower organic consumption than Denmark. ${ }^{3}$

Food scares. Since organic farming is often seen as a safe and clean agricultural production method, it offers an alternative to consumers when conventional agricultural production methods are questioned as a consequence of food scares, a phenomenon 'generally associated with spiralling public anxiety over food safety incidents' (Knowles et al., 2007, p. 43). Thus, one should expect that variance in food scares could explain varying consumption levels (Dimitri and Oberholtzer, 2005; DuPois, 2000). The crude measure in Table 4 hints that this is probably not the

\footnotetext{
${ }^{3}$ Using more observations than here, Hamm and Gronefeld (2004, p. 125) find a correlation between sales channels and consumption, but do not control for alternate explanations and do not consider the likely feed-back effect from demand to supermarket supply. Hence, the alleged effect of sales channels is very uncertain.
} 
case. All four countries have experienced food scares, but to varying degrees. While Sweden and the US have had few experiences with food scares, they have been more frequent in Denmark but have not escalated into major scares (Knowles et al., 2007; DuPois, 2000). In the UK, Mad Cow Disease (BSE) in the 1990s and the outbreak of Foot and Mouth Disease in 2001 developed into major food scares in which conventional agricultural production methods were seriously questioned (Baggott, 1998; Hindmoor, 2009; Vogel, 2003), but this did not lead to a high level of organic consumption in the UK as would be expected.

Prosperity. The literature on environmental performance suggests that we can expect better environmental performance, and thus higher organic consumption, in affluent countries (e.g., Scruggs, 2003, Ch. 3). However, in our sample prosperity is a poor predictor of consumption since Denmark has the highest level of consumption but is not the most prosperous country, which corresponds to Sønderskov (2009) who shows that wealth does not significantly affect aggregate consumption levels among 20 European countries.

Neo-corporatism. A number of studies suggest that corporatism is the most important predictor of environmental performance (e.g. Crepaz, 1995; Scruggs, 2003) because it facilitates cooperation between state, business and labour. Therefore, this factor is included in our analysis although the literature does not specifically predict that neo-corporatist institutions should lead to a higher level of organic food consumption. Table 4 contains several measures for the degree of corporatism in the four countries. Denmark is far more corporatist than the US and UK, but Sweden is even more corporatist on all four measures applied. However, the high level of corporatism in Sweden is not reflected in a high level of organic consumption, which indicates that corporatism does not affect consumption.

In sum, none of the alternate factors are able to explain the cross-national variance in consumption shown in Table 3 because the actual pattern of cross-national variance in these alternate variables does not conform to the predicted pattern.

\section{Alternate explanation at the individual level}


In addition to the alternate explanations examined above, several individual level factors could be the real cause of the observed pattern of organic consumption across the four countries. Crossnational variation in consumption levels may not be ascribed to policy, but to cross-national variation in individual level characteristics. To assess the impact of these alternate factors on consumption, this section briefly discusses possible individual level explanations and tests if one or more of these are the real explanation behind the pattern of consumption observed above. The list of potential individual level explanations is long but the factors listed in table 5 have generally been accepted as influential (Lockie et al., 2002; Sønderskov, 2009; Thompson, 1998; Wier and Calverley, 2002).

Whether the observed cross-national differences in organic consumption are caused by individual level differences is tested using survey data from the four countries. We rely on a unique surveythe COP survey-which is tailor-made for this purpose. It contains data on self-reported organic consumption as well as all of the most important potential explanatory factors found in the literature. ${ }^{4}$ It is analysed if the cross-national pattern found in Table 3 still exists when controlling for individual level factors. This is done by regressing organic consumption on the individual level explanations as well as country of residence, which in accordance with the comparison of policy types above indicates different organic sector policies. Thus, if residency affects consumption in the way predicted after controlling for relevant individual level factors it supports our hypothesis and demonstrates the utility of the typology.

The dependent variable in this analysis - level of organic food consumption -is measured using three items about consumption of three foods groups: 'Think about your shopping in the past six months: How large a share of your consumption has been organic within the following food

\footnotetext{
${ }^{4}$ The survey is a self-administered web survey with participants sampled from standing panels. It consists of representative samples (on various demographic parameters) of approximately 1,000 respondents from the UK, USA, Denmark, and Sweden. Only respondents not living with their parents (or grandparents) are sampled to ensure that they actually have a say on food consumption (Stolle, Hooghe \& Micheletti, 2005, pp. 245-69). The response rate varies between $39 \%$ and $57 \%$ across countries. Although this is rather low, there is no particular reason to expect substantial sampling bias as non-responders did not know the topic before refusing to participate. The fieldwork was conducted by AC Nielsen and Survey Sampling International in April/May 2008. The codebook is available upon request.
} 
groups?' (Dairy products, Fruit and vegetables, and Meat). The respondents answered on a scale from 1-5, where 1 signifies that organic food comprises an insignificant share of consumption within each food type, and 5 signifies that all or almost all consumption of the particular food type is organic. The measure is the mean of the three items. ${ }^{5}$ Reliance on self-reported behaviour is not unproblematic. In relation to socially desirable behaviour like organic food consumption, people tend to exaggerate their pro-social behaviour (Cummings et al., 1995), which is also evident in Table 3. According to our data, the average level of consumption is above 2 in all countries (on a scale from 1-5), while the actual level is more like 'an insignificant share' i.e. close to 1 on our measure. Part of this difference could be due to differences in scope between the measures. The survey asks consumers to report on the three most sold organic food categories, while the official data on consumption shown in Table 3 include all organic food categories, including organic products with very little market shares. Nevertheless, some over-reporting is probably present in our data. This questions the reliability of the dependent variable and hence potentially undermines the validity of the results obtained with these data. On the other hand, if the level of over-reporting is uncorrelated with the explanatory variable, the problem is less severe. If so, the reported consumption level is unreliable, but the estimated effects of the independent variables are unbiased and valid (Wooldridge, 2008, p. 316). Obviously, our main concern here is the effect of the country of residence variable. It is difficult to say if respondents' level of exaggeration varies across countries, but a glance at Table 3 reveals that the cross-country pattern of the aggregated survey data corresponds with the cross-country pattern of actual consumption with Denmark having the highest organic market share, while the others are almost at par. This is reassuring as it suggests a fairly constant level of exaggeration. Thus, there are no indications that the use of selfreported behaviour poses a serious problem to our analysis.

Table 5 provides details on the measures of the independent variables. Some of the variables included do not vary substantially across countries to account for cross-national differences; most notably gender and age distribution. This implies that it is unnecessary to include these variables in the analysis, but for the sake of comprehensiveness we do, however, include them.

\footnotetext{
${ }^{5}$ For each food type, the respondent can answer that she does not eat or drink this type of food. In such cases the score is the mean of the remaining food types. To ensure reliability, only respondents who eat/drink at least two food types are included.
} 
Table 5 about here

Individual level analysis

Table 6 shows the results of the individual level analysis. Model I is the baseline model which excludes all control variables. The coefficients correspond to the measure reported in the bottom of Table 3, and it confirms the overall pattern in Table 3; Danes consumes significantly more organic food than consumers in the three other countries. In Model II social background variables are added, which does not alter the effect of the residency variable much. Thus, social background does not explain the country level variance observed in Model I and Table 3. This is hardly surprising since the social background variables do not vary substantially across the four countries. It must be mentioned that there is a drastic reduction in sample size in Model II compared to Model I, which is mainly caused by the inclusion of the income variable. Many respondents did not answer that question.

Table 6 about here

In Model III, the two environmental attitudinal variables are added. In contrast to the background variables, these variables reduce the effect of the country of residence variable. This indicates that part of the observed differences between aggregate consumption can be ascribed to higher levels of environmental concern, postmaterialist values and/or a more pronounced negative perception of conventional agriculture in Denmark. However, the country of residence is still highly influential, which corroborates our hypothesis. However, the coefficient for Swedish residency suggests that the higher Swedish consumption cannot be ascribed to its policy, but rather to the values of its citizens. The Swedes has the lowest level of consumption when holding environmental values constant. However, as we shall see this pattern does not persist into the subsequent models. 
In Model IV all variables are entered. Not surprisingly, variables relating more or less directly to organic food are very influential. Especially trust in labelling system is an important predictor of organic consumption (recall that all variables, except age, are scaled from $0-1$ ). When these influential variables are included, the effect of Danish residency drops further (as well as some of the background variables). Nevertheless, the difference between the Danes and the residents of the other countries is still significant. This strongly supports our hypothesis. Moreover, the full model also shows that the Swedes are again ranked second when holding all individual level explanations constant, which also supports our hypothesis. Note however, that this difference is not statistically significant at conventional levels. The rather low R-squares in all models should also be noted; the models clearly cannot fully explain individual consumption. However, our objective here is not to explain consumption, but merely to examine the effect of policy (operationalized by country of residence). Since the most widely accepted variables affecting organic consumption suggested in the literature have been controlled for there is no reason to expect that the low R-squares are caused by omitted variables. Thus, the estimated effect of residency is most likely unbiased.

However, Model IV may underestimate the policy effect. As described above, the labelling and certification systems vary across the four countries and this difference in policy may affect consumers trust in certification and labelling systems. A preliminary analysis confirms this; Danish residents report significantly higher trust in the labelling system $(P<0.001)$ (see also Sønderskov and Daugbjerg, forthcoming). Thus, some of the effect of trust in Model VI can probably be ascribed to policy differences in labelling systems. Therefore, trust in the labelling system is omitted from Model $\mathrm{V}$, which makes the country of residence variable almost as influential as in Model III. Although all variation in trust is unlikely to be caused by policy, Model V suggests that the effect of policy is larger than reported in Model IV. This underscores the significance of the policy variable.

In sum, the regression analysis using the survey data by and large corroborated the results obtained with aggregate data in Table 3. Danes consume more organic food than consumers in the three other countries. This result stands after taking into account the most important individual 
level factors believed to impact on organic consumption. The Swedes consumes slightly more organic food than the Americans and the British and after taking individual level differences into account, no differences exist between the two last mentioned. Moreover, the pattern matching analysis suggests that variation in organic food policy is the only systemic factor that can explain country level differences in organic food consumption. Hence, our analysis demonstrates that policy type affects performance. Our analysis indicates that an active market development policy is better suited to increase performance than other policy types and that a supply driven policy slightly outperforms a passive market development policy.

\section{CONCLUSION}

A key argument of this article is that when environmental policy performance is compared across countries we should focus on the policy instrument packages rather than on individual instruments. Hence, we developed a policy typology applicable for government intervention aimed at creating green markets. The utility of the typology was demonstrated in an empirical analysis, testing whether predictions on policy performance derived from the typology could be sustained. We demonstrated that limited government intervention into the organic food sector in the UK and the US is an important factor explaining the low level of organic consumption in these two countries. Significant growth in green markets is most likely to result where a combination of policy instruments directed at the supply-side and demand-side of the market is simultaneously implemented, as demonstrated by the Danish experience. The Swedish case indicates that concentrating government intervention on the supply-side by providing producer subsidies does not have a major impact on growth. Unfortunately, we have not been able to ascertain an instance of organic food policy which concentrates only on manipulating demand for organic food and therefore we are unable to conclude whether this would be sufficient to expand the market.

One should be careful about drawing general conclusions on the basis of the four cases analysed in this article. However, our findings do suggest that environmental policies addressing industries could potentially become more effective if policy instruments affecting the demand-side of the market are given more prominence in the policy instrument package. The assumption that 
industries' costs of implementing supply-side instruments can be retrieved in the marketplace is not often shared by the industry subject to intervention. Industries fearing that a market for their higher priced produce would not emerge are likely to put considerable political effort into blocking the introduction of such environmental measures, or alternatively try to shape them in ways which weaken their impact on production costs. So, in addition to contributing with an independent environmental impact, more emphasis on demand-side instruments in environmental policy instrument packages could potentially increase industries' willingness to accept more effective supply-side measures. In other words, there is a need for 'smart' environmental policies, that is, imaginative policy instrument combinations promising improved environmental performance which, at the same time, are acceptable to industries and the public (Gunningham et al. 1998, pp. 4, 11).

An obvious question for further research is the ability of governments to design and implement instrument packages which include demand-side instruments and to ensure that they interact positively with supply-side instruments. Increased use of demand-side instruments in combination with supply-side instruments in environmental policy is not only a question of awareness of the performance potential. It is also a question of governing capacities. The concepts of policy capacity, administrative capacity and state capacity may be useful in the analyses of governing capacities of governments in environmental policy making. Policy capacity refers to 'the ability to marshal the necessary resources to make intelligent choices about and set strategic directions for the allocation of scarce resources to public ends', administrative capacity is defined as 'the ability to manage effectively the human and physical resources for delivering the outputs of government and state capacity refers to 'the state's ability to mobilize social and economic support and consent for the achievement of public-regarding goals' (Painter and Pierre, 2005, p. 2). These capacities can be developed within the state but also in collaboration with environmental and producer groups. The ability to develop such capacities can be expected to have an important impact on whether government will succeed in implementing 'smart' and effective policy instrument packages. Variation in these capacities may also explain differences in environmental policy choices across countries and even in environmental instrument packages applied across 
policy sectors within the same country. Thus, there are still important questions relating to environmental policy performance which need to be answered.

\section{ACKNOWLEDGEMENT}

Earlier versions of this paper were presented at General Conference of the ECPR, 10-12 September, 2009 in Berlin and in seminars at Aarhus University, University of Canberra, the Fenner School of Environment and Society, ANU and University of Southern Queensland. The authors are grateful to the participants in these events and in particular to three anonymous reviewers of this journal for helpful comments. The financial support of ICROFS (DARCOF III) is appreciated.

\section{REFERENCES}

Agromilagro (2010). Laenderportraits. Available from:

http://www.agromilagro.de/laenderportraits.html [Accessed May 3 2010].

Andersen, M. S. (1994). Governance by Green Taxes: Making Pollution Prevention Pay. Manchester: Manchester University Press.

Baggot, R. (1998). 'The BSE crisis: public health and the 'risk society', in P. Gray and P. 't Hart (eds.), Public Policy Disasters in Western Europe. London: Routledge, pp. 61-78.

Boström, M. (2006). 'Regulatory Credibility and Authority through Inclusiveness: Standardization Organizations in Cases of Eco-Labelling', Organization, 13 (3), 345-367.

Carter, N. (2007). The Politics of the Environment: ideas, activism, policy, 2nd edition. Cambridge: Cambridge University Press.

Crepaz, M. M. L. (1995). 'Explaining National Variations of Air Pollution Levels: Political Institutions and their Impact on Environmental Policy-Making', Environmental Politics, 4 (3), 391-414.

Cummings, R. G., Harrison, G. W., \& Rutstrom, E. E. (1995). 'Homegrown Values and Hypothetical Surveys: Is the Dichotomous Choice Approach Incentive-Compatible?', American Economic Review, 85 (1), 260-266.

Daugbjerg, C. and Halpin, D. (2008). 'Sharpening up research on organics: why we need to integrate sectoral policy research into mainstream policy analysis', Policy Studies, 29 (4), 393-404.

Daugbjerg, C., Tranter, R., Hattam, C. and Holloway, G. (forthcoming) 'Modelling the Impacts of Policy on Entry into Organic Farming: Evidence from Danish-UK Comparisons, 1989-2007.' Forthcoming in Land Use Policy. 
Dimitri, C. and Oberholtzer, L. (2005). Market-Led Growth vs. Government-Facilitated Growth: Development of the U.S. and EU Organic Agricultural Sectors. USDA/ERS.

DuPuis, E. M. (2000). 'Not in my body: BGH and the rise of organic milk', Agriculture and Human Values, 17 (3), 285-295.

Eliadis, P., Hill, M. and Howlett, M. (2005). Introduction in: P. Eliadis, M. Hill and M. Howlett (eds.) Designing Government. Montreal: McGill/Queens University Press, 3-18.

Enevoldsen, M. (2005). The theory of environmental agreements and taxes. Cheltenham, UK: Edward Elgar.

Ergas, H. (2010). 'New policies create a new politics: issues of institutional design in climate change policy', Australian Journal of Agricultural and Resource Economics, 54 (2), 143-164.

Gunningham, N., Grabosky, P. and Sinclair, D. (1998) Smart Regulation: designing Environmental Policy. Oxford: Clarendon Press.

Halpin, D., Daugbjerg, C. and Schvartzman, Y. (forthcoming). 'Interest Group Capacities and Infant Industry Development: State-sponsored Growth in Organic Farming'. Forthcoming in International Political Science Review.

Hamm, U. and Gronefeld, F. (2004). The European market for organic food: Revised and updated analysis. Aberystwyth: School of Management and Business.

Hicks, A. and Kenworthy, L. (1998). 'Cooperation and Political Economic Performance in Affluent Democratic Capitalism', American Journal of Sociology, 103 (6), 1631-1672.

Hindmoor, A. (2009). Explaining Networks through Mechanisms: Vaccination, Priming and the 2001 Foot and Mouth Disease Crisis. Political Studies, 57 (1), 75-94.

Hood, C. (1983). The Tools of Government. London: Macmillan.

Hood, C. (2007). 'Intellectual Obsolescence and Intellectual Makeovers: Reflections on the Tools of Government after Two Decades', Governance, 20 (1), 127-144.

Howlett, M. (2005). 'What is a Policy Instrument?' In: P. Eliadis, M. Hill and M. Howlett (eds.) Designing Government. Montreal: McGill/Queens University Press, pp. 31-50.

Howlett, M. (2009). 'Governance modes, policy regimes and operational plans: A multilevel nested model of policy instrument choice and policy design', Policy Sciences, 42 (1), 73-89.

Inglehart, R. (1997). Modernization and postmodernization. Princeton, N.J: Princeton University Press.

Jahn, D. (1998). 'Environmental performance and policy regimes: Explaining variations in 18 OECDcountries', Policy Sciences, 31 (2), 107-131. 
Jänicke, M. (1992). 'Conditions for Environmental Policy Success: An International Comparison', in Markus Jachtenfuchs and Michael Strübel (eds.), Environmental Challenges in Europe:

Assessments, Challenges and Perspectives. Baden-Baden: Nomos Verlagsgesellschaft, pp. 71-97.

Johnson, R. (2008). 'Organic Agriculture in the United States: Program and Policy issues', CRS Report for Congress, updated November 2008. Washington: Congressional Research Service.

Jordan, A., Wurzel, R. K. W., \& Zito, A. (2005). 'The Rise of 'New' Policy Instruments in Comparative Perspective: Has Governance Eclipsed Government?', Political Studies, 53 (3), 477-496.

Kenworthy, L. (2003). 'Quantitative Indicators of Corporatism', International Journal of Sociology, 33 (3), 10-44.

Knowles, T., Moody, R., and McEachern, M. G. (2007). 'European food scares and their impact on EU food policy', British Food Journal, 109 (1), 43-67.

Lascoumes and Le Gales (2007). 'Introduction: Understanding Public Policy through Its Instruments - From the nature of Instruments to the Sociology of Public Policy Instrumentation', Governance, $20(1), 1-21$.

Lehmbruch, G. (1984). 'Concertation and the Structure of Corporatist Networks', in J. H. Goldthope (Ed.), Order and Conflict in Contemporary Capitalism. Oxford: Clarendon Press, pp. 60-80.

Lijphart, A. \& Crepaz, M. M. L. (1991). 'Corporatism and Consensus Democracy in Eighteen Countries: Conceptual and Empirical Linkages', British Journal of Political Science, 21 (2), 235-246.

Lindblom, C. E. (1958). 'Tinbergen on policy-making', Journal of Political Economy, 66 (6), 531-538.

Linder, S. H. and Peters, B. G. (1989). 'Instruments of government: perceptions and contexts', Journal of Public Policy, 9 (1), 35-58.

Lockie, S., Lyons, K., Lawrence, G., \& Mummery, K. (2002). 'Eating “Green”: Motivations Behind Organic Food Consumption in Australia', Sociologia Ruralis, 42 (1), 23-40.

Lowi, T. J. (1972). 'Four Systems of Policy, Politics, and Choice', Public Administration Review, 32 (4), 298-310.

Oberholtzer, L., Dimitri, C. and Greene, C. (2005). Price Premiums Hold on as U.S. Organic Produce Market Expands. Electronic Outlook Report from the Economic Research Service, USDA. Available from http://www.ers.usda.gov/publications/vgs/may05/VGS30801/VGS30801.pdf [Accessed January 15 2009].

OECD (2007). Instrument Mixes for Environmental Policy. Paris: OECD.

Oikonomou, V., Flamos, A., and Grafakos, S. (2010). 'Is blending of energy and climate policy instruments always desirable?' Energy Policy, 38 (8), 4186-4195. 
Organic Trade Association (2009). The Organic Trade Association's 2009 Organic Industry Survey Executive Summary. Greenfield: Organic Trade Association. Available from:

http://www.ota.com/pics/documents/01a_OTAExecutiveSummary.pdf [Accessed November 15 2010].

Painter, M. and Pierre, J. (2005). 'Unpacking policy capacity: Issues and themes', in M. Painter and J. Pierre (eds.), Challenges to State Policy Capacity: Global Trends and Comparative Perspectives. Basingstoke: Palgrave, pp. 1-18.

Pressman, J. and Wildavsky, A. (1983 [1973]). Implementation (3rd ed.), Berkeley: University of California Press.

Rippin, M. (2010a). Organic market data for 2006/2007. Available from: http://www.agromilagro.de/downloads/biofach2008_eumarket.pdf [Accessed 3 May 2010].

Rippin, M. (2010b). Organic market data for 2007/2008. Available from: http://orgprints.org/15482/4/rippin-2009-eu-market.pdf [Accessed 3 May 2010].

Rydén, Reine (2003). 'Medvindens tid: Ekologiska Lantbrukarna och jordbrukspolitiken 1985-2000', Ekologiskt Lantbruk, 36. Uppsala: Centrum för uthålligt lantbruk.

Scruggs, L. A. (2003). Sustaining abundance: environmental performance in industrial democracies. Cambridge: Cambridge University Press.

Sønderskov, K. M. (2009). 'Different goods, different effects: Exploring the effects of generalized social trust in large- $N$ collective action', Public Choice, 140 (1), 145-160.

Sønderskov, K. M and Daugbjerg, C. (forthcoming). 'The state and consumer confidence in ecolabeling: organic labeling in Denmark, Sweden, the United Kingdom and the United States'. Forthcoming in Agriculture and Human Values.

Stolle, D., Hooghe, M., and Micheletti, M. (2005). 'Politics in the Supermarket: Political Consumerism as a Form of Political Participation', International Political Science Review/Revue Internationale de Science Politique, 26 (3), 245-269.

Svendsen, G. T. (1998). Public Choice and Environmental Regulation: Tradable permit Systems in the United States and $\mathrm{CO}_{2}$ Taxation in Europe. Cheltenham: Edward Elgar.

Swank, D. (2001). 'Political Institutions and Welfare State Restructuring: The Impact of Institutions on Social Policy Change in Developed Democracies', in P. Pierson (ed.), The New Politics of the Welfare State. Oxford: Oxford University Press, pp. 197-237.

Thompson, G. D. (1998). 'Consumer Demand for Organic Foods: What We Know and What We Need to Know', American Journal of Agricultural Economics, 80 (5), 1113-1118.

Tinbergen, J. (1952). On the theory of economic policy. Amsterdam: North Holland Publishing. 
USDA/NRCS (2008). Environmental Quality Incentives Program. Available from:

http://www.nrcs.usda.gov/PROGRAMS/EQIP/ [Accessed 27 January 2009].

Vedung, E. (1998). 'Policy Instruments: Typologies and Theories', in M. Bemalmans-Videc, R. C. Rist and E. Vedung (eds.), Carrots, Sticks and Sermons: Policy Instruments and Their Evaluation. New Brunswick: Transaction Books, pp. 21-58.

Vogel, D. (2003). 'The Hare and the Tortoise Revisited: The New Politics of Consumer and Environmental Regulation in Europe', British Journal of Political Science, 33 (4), 557-580.

WDI Online (2007). World Development Indicators Online [Accessed 15 January 2009].

Wier, M. and Calverley, C. (2002). 'Market potential for organic foods in Europe', British Food Journal, 104 (1), 45-62.

Willer, H. and Yussefi, M. (2000). Ökologische Agrarkultur Weltweit - Statistiken und Perspektiven/Organic Agriculture Worldwide - Statistics and Future Prospects, 2nd edition. Bad Dürkheim: Stiftung Ökologie \& Landbau.

Wilson, J. Q. (1973). Political Organizations. New York: Basic Books.

Wooldridge, J. M. (2008). Introductory econometrics: a modern approach, 4th edition. Boston: South Western Cengage Learning.

Yin, R. K. (2003). Case Study Research: Design and Methods, 3rd edition. Thousand Oaks: Sage Publications.

$\varnothing$ kologisk Landsforening (2009). Økologisk markedsnotat. Aabyh $\varnothing$ j: $\varnothing$ kologisk Landsforening, Available from: http://www.okologi.dk/media/229957/markedsnotat2009.pdf [Accessed November 15 2010]. 
Table 1. Policy typology

Emphasis on supply-side instruments

Low

High

\begin{tabular}{lccc}
$\begin{array}{l}\text { Emphasis on } \\
\text { demand-side }\end{array}$ & Low & I: Passive market development & II: Supply driven policy \\
instruments & High & III: Demand creation policy & IV: Active market \\
& & development policy \\
\hline
\end{tabular}


Table 2: Inventory of policy instruments potentially applied in the four policy types

\begin{tabular}{|c|c|c|c|c|c|c|c|c|c|}
\hline \multirow[b]{2}{*}{$\begin{array}{l}\text { Substantive supply-side } \\
\text { instruments }\end{array}$} & \multicolumn{4}{|c|}{ Policy type } & \multirow[b]{2}{*}{$\begin{array}{l}\text { Substantive demand-side } \\
\text { instruments }\end{array}$} & \multicolumn{4}{|c|}{ Policy type } \\
\hline & I & II & III & IV & & I & II & III & IV \\
\hline $\begin{array}{l}\text { Informative: government-sponsored } \\
\text { dissemination of knowledge on } \\
\text { green production methods }\end{array}$ & & $\mathrm{x}$ & & $\mathrm{x}$ & $\begin{array}{l}\text { Informative: government- } \\
\text { sponsored marketing } \\
\text { campaigns to persuade } \\
\text { consumers to buy green } \\
\text { produce }\end{array}$ & & & $\mathrm{x}$ & $\mathrm{x}$ \\
\hline $\begin{array}{l}\text { Regulation: prohibit or prescribe } \\
\text { particular production activities }\end{array}$ & $\mathrm{x}$ & $\mathrm{x}$ & $\mathrm{x}$ & $\mathrm{x}$ & $\begin{array}{l}\text { Regulation: prescribe state } \\
\text { institutions to purchase green } \\
\text { products }\end{array}$ & & & $\mathrm{x}$ & $\mathrm{x}$ \\
\hline $\begin{array}{l}\text { Economic: apply positive economic } \\
\text { incentives (green producer } \\
\text { subsidies) or negative economic } \\
\text { incentives (environmental charges) }\end{array}$ & & $\mathrm{x}$ & & $\mathrm{x}$ & $\begin{array}{l}\text { Economic: create economic } \\
\text { incentives for consumers to buy } \\
\text { green produce (e.g. lower sales } \\
\text { taxes for green products) }\end{array}$ & & & $\mathrm{x}$ & $\mathrm{x}$ \\
\hline $\begin{array}{l}\text { Organization: establishing research } \\
\text { and extension services }\end{array}$ & & $\mathrm{x}$ & & $\mathrm{x}$ & $\begin{array}{l}\text { Organization: accredit or } \\
\text { operate eco- labelling systems }\end{array}$ & $(\mathrm{x})$ & $(\mathrm{x})$ & $\mathrm{x}$ & $\mathrm{x}$ \\
\hline
\end{tabular}

Notes: Policy type I: Passive market development policy; II: Supply driven policy; III: Demand creating policy; IV: Active market development policy. 
Table 3. Organic food consumption in the US, UK, Sweden and Denmark

\begin{tabular}{|c|c|c|c|c|}
\hline & USA & UK & Sweden & Denmark \\
\hline \multicolumn{5}{|c|}{ Organic share of the total turnover in the food market (\%) } \\
\hline 1997 & $0.8^{\mathrm{a}}$ & $0.4^{b}$ & $0.6^{\mathrm{b}}$ & $2.5^{\mathrm{b}, \mathrm{g}}$ \\
\hline 1998 & $0.9^{\mathrm{a}}$ & & & $3.3^{\mathrm{g}}$ \\
\hline 1999 & $1.1^{\mathrm{a}}$ & & & $3.7^{\mathrm{g}}$ \\
\hline 2000 & $1.2^{\mathrm{a}}$ & & & $3.7^{\mathrm{g}}$ \\
\hline 2001 & $1.4^{\mathrm{a}}$ & $0.9^{c}$ & $1.7^{\mathrm{c}}$ & $3.6^{\mathrm{c}, \mathrm{g}}$ \\
\hline 2002 & $1.6^{\mathrm{a}}$ & & & $3.7 \mathrm{~g}$ \\
\hline 2003 & $1.9^{\mathrm{a}}$ & & & $3.7 \mathrm{~g}$ \\
\hline 2004 & $2.2^{\mathrm{a}}$ & $2.2^{d}$ & $3.0^{d}$ & $4.4^{\mathrm{d}, \mathrm{g}}$ \\
\hline 2005 & $2.5^{\mathrm{a}}$ & & & $4.2^{\mathrm{e}, \mathrm{g}}$ \\
\hline 2006 & $2.8^{\mathrm{a}}$ & $2.4^{\mathrm{e}}$ & $2.4^{\mathrm{e}}$ & $4.6^{\mathrm{g}}$ \\
\hline 2007 & $3.2^{\mathrm{a}}$ & $1.6^{\dagger}$ & $3.0^{\dagger}$ & $5.9^{\mathrm{t}, \mathrm{g}}$ \\
\hline 2008 & $3.5^{\mathrm{a}}$ & & & $6.6^{\mathrm{g}}$ \\
\hline Average (1997-2008) & 1.9 & 1.5 & 2.1 & 4.1 \\
\hline Average (2004-2007) & 2.7 & 2.1 & 2.8 & 4.8 \\
\hline $\begin{array}{l}\text { Level of organic consumption } 2008 \\
\text { (survey data) }\end{array}$ & $2.02^{h}$ & $2.03^{h}$ & $2.04^{h}$ & $2.41^{\mathrm{h}}$ \\
\hline
\end{tabular}

Notes and sources: When data from two sources differ, we use the average figure. ${ }^{a}$ : Organic Trade Association (2009: Table 1.2); ${ }^{\text {b }}$ : Willer \& Yussefi (2000: Table 7); ${ }^{\text {: }}$ Hamm \& Gronefeld (2004: Table 4.5); ${ }^{\text {d: }}$ Agromilagro (2010); ${ }^{\mathrm{e}}$ : Rippin (2010a); ${ }^{\mathrm{f}}$ : Rippin (2010b); ${ }^{\mathrm{g}}$ : Ø kologisk Landsforening (2009: Figure 1), ${ }^{\mathrm{h}}:$ The numbers are the average level of self reported consumption on a scale from 1-5 (cf. below). 
Table 4. Data on alternate explanations

\begin{tabular}{|c|c|c|c|c|}
\hline & $\begin{array}{l}\text { United } \\
\text { States }\end{array}$ & $\begin{array}{l}\text { United } \\
\text { Kingdom }\end{array}$ & Sweden & Denmark \\
\hline Average price premiums 2001 & approx. $100^{\mathrm{a}}$ & $51^{b}$ & $39^{b}$ & $62^{b}$ \\
\hline $\begin{array}{l}\text { Share of organic food sales in } \\
\text { general food shops } 2001 \text { (\%) }\end{array}$ & $47(2003)^{a}$ & $82^{b}$ & $90^{b}$ & $80^{b}$ \\
\hline Food scares ${ }^{c}$ & Low & High & Low & Medium \\
\hline \multicolumn{5}{|c|}{ Wealth (GDP per capita, PPP 2005 US\$) $^{d}$} \\
\hline 2001 & 38,894 & 28,983 & 29,228 & 32,056 \\
\hline 2007 & 43,227 & 32,766 & 33,760 & 35,062 \\
\hline \multicolumn{5}{|l|}{ Neo-corporatism ${ }^{\mathrm{e}}$} \\
\hline Lijphart-Crepaz (pre 1990) ${ }^{f}$ & -1.34 & -0.86 & 1.40 & 0.52 \\
\hline 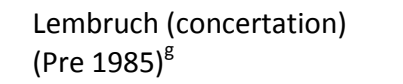 & 1 & 2 & 4 & 3 \\
\hline Swank $(1994)^{\mathrm{h}}$ & -1.19 & -0.84 & 1.30 & 0.66 \\
\hline Hicks-Kenworthy (1994) ${ }^{i}$ & 0.01 & 0.07 & 0.78 & 0.61 \\
\hline
\end{tabular}

Notes and sources: ${ }^{a}$ Oberholtzer, Dimitri and Greene 2005; ${ }^{\text {b. Hamm \& Gronefeld 2004, Table }}$ $8-4 ;{ }^{c}$ See text for sources; ${ }^{d}$ WDI Online 2007, NY.GDP.PCAP.PP.KD; ${ }^{e}$ All data are from

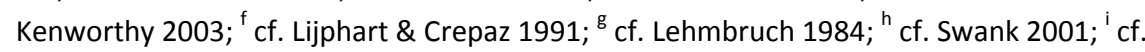
Hicks \& Kenworthy 1998. 
Table 5. Measurement of the independent variables

\begin{tabular}{|c|c|}
\hline Concept/(Variable name) & Details \\
\hline $\begin{array}{l}\text { Country of Residence } \\
\text { (Sweden, UK, USA, Denmark) }\end{array}$ & - \\
\hline Gender (Female) & Dummy variable; $1=$ female \\
\hline Age (Age) & Naturally coded \\
\hline Nativity (Native) & Dummy; $1=$ Native \\
\hline Urban living (Urban) & Dummy; $1=$ respondent is living in a city of more than 50,000 inhabitants \\
\hline Children in household (Children) & Dummy variable; $1=$ one or more children (under age 20 ) is living in household \\
\hline Income (Income) & 10 country equivalent categories; Rescaled from $0-1 ; 1=$ High income \\
\hline Education (Education) & 9-12 categories depending on country; Rescaled $0-1 ; 1=$ Highly educated \\
\hline $\begin{array}{l}\text { Environmental values } \\
\text { (Materialist, mixed, postmaterialist) }\end{array}$ & $\begin{array}{l}\text { Based on the four item postmaterialism battery ; Postmaterialist=strong } \\
\text { environmental values }\end{array}$ \\
\hline $\begin{array}{l}\text { Perceptions of the safety and environmental } \\
\text { friendliness of conventional agriculture } \\
\text { (Conventional unfriendly) }\end{array}$ & $\begin{array}{l}\text { "Conventional agriculture - i.e. non-organic agriculture - is very environmentally } \\
\text { friendly"; } 5 \text { categories; Scaled } 0-1 ; 1=\text { "Completely disagree" }\end{array}$ \\
\hline $\begin{array}{l}\text { Perceptions of the healthiness of organic } \\
\text { produce } \\
\text { (Healthiness) }\end{array}$ & $\begin{array}{l}\text { Dummy; } 1=\text { respondent chose either "Organic products contain more vitamins } \\
\text { and other important nutrients than non-organic products", "There are fewer } \\
\text { residual pesticides and medicines in organic products", or both when asked to } \\
\text { chose the two best descriptions of organic products (out of } 7 \text { possibilities) }\end{array}$ \\
\hline $\begin{array}{l}\text { Trust in the labelling system } \\
\text { (Label trust) }^{\mathbf{b}}\end{array}$ & $\begin{array}{l}\text { "You can trust that products marketed as organic actually are organic in the } \\
\text { majority of cases"; } 5 \text { categories, Scaled } 0-1 ; 1=\text { "Completely agree" }\end{array}$ \\
\hline $\begin{array}{l}\text { Availability of organic products } \\
\text { (Availability) }^{\mathbf{b}}\end{array}$ & $\begin{array}{l}\text { "The shops I frequent sell few organic products"; } 5 \text { categories; } \\
\text { Scaled } 0-1 ; 1=\text { "Completely disagree" }\end{array}$ \\
\hline
\end{tabular}


Table 6. Predicting organic consumption at the individual level (OLS)

\begin{tabular}{|c|c|c|c|c|c|}
\hline & Model I & Model II & Model III & Model IV & Model V \\
\hline \multicolumn{6}{|l|}{ Country of residence } \\
\hline Denmark & & & Reference & & \\
\hline \multirow[t]{2}{*}{ Sweden } & $-0.37 * * *$ & $-0.39 * * *$ & $-0.33 * * *$ & $-0.14 * *$ & $-0.23 * * *$ \\
\hline & $(0.05)$ & $(0.05)$ & $(0.06)$ & $(0.06)$ & $(0.06)$ \\
\hline \multirow[t]{2}{*}{ UK } & $-0.38 * * *$ & $-0.40 * * *$ & $-0.27 * * *$ & $-0.18 * * *$ & $-0.27 * * *$ \\
\hline & $(0.05)$ & $(0.06)$ & $(0.07)$ & $(0.07)$ & $(0.07)$ \\
\hline \multirow[t]{2}{*}{ USA } & $-0.39 * * *$ & $-0.42 * * *$ & $-0.27 * * *$ & $-0.19 * *$ & $-0.32 * * *$ \\
\hline & $(0.06)$ & $(0.07)$ & $(0.07)$ & $(0.07)$ & $(0.07)$ \\
\hline \multirow[t]{2}{*}{ Female } & & $0.10 * *$ & $0.12^{* * *}$ & 0.04 & $0.08^{*}$ \\
\hline & & $(0.04)$ & $(0.04)$ & $(0.04)$ & $(0.04)$ \\
\hline \multirow[t]{2}{*}{ Age } & & $0.00 * * *$ & $0.00^{*}$ & $0.00 * * *$ & 0.00 \\
\hline & & $(0.00)$ & $(0.00)$ & $(0.00)$ & $(0.00)$ \\
\hline \multirow[t]{2}{*}{ Native } & & $-0.26 * * *$ & $-0.25 * *$ & $-0.25^{* *}$ & $-0.24 * *$ \\
\hline & & $(0.09)$ & $(0.10)$ & $(0.10)$ & $(0.10)$ \\
\hline \multirow[t]{2}{*}{ Urban } & & $0.13^{* * *}$ & $0.10^{* *}$ & 0.04 & 0.07 \\
\hline & & $(0.04)$ & $(0.04)$ & $(0.04)$ & $(0.04)$ \\
\hline \multirow[t]{2}{*}{ Children } & & 0.01 & 0.03 & 0.02 & 0.03 \\
\hline & & $(0.04)$ & $(0.05)$ & $(0.05)$ & $(0.05)$ \\
\hline \multirow[t]{2}{*}{ Income } & & $0.18^{* *}$ & $0.22 * *$ & 0.15 & 0.14 \\
\hline & & $(0.09)$ & $(0.10)$ & $(0.10)$ & $(0.10)$ \\
\hline \multirow[t]{2}{*}{ Education } & & $0.26 * * *$ & 0.14 & 0.09 & 0.09 \\
\hline & & $(0.08)$ & $(0.09)$ & $(0.09)$ & $(0.09)$ \\
\hline \multicolumn{6}{|l|}{ Environmental values } \\
\hline Materialist & & & Reference & & \\
\hline \multirow[t]{2}{*}{ Mixed } & & & $0.12 * *$ & 0.05 & 0.06 \\
\hline & & & $(0.05)$ & $(0.05)$ & $(0.05)$ \\
\hline \multirow[t]{2}{*}{ Postmaterialist } & & & $0.44 * * *$ & $0.35^{* * *}$ & $0.40 * * *$ \\
\hline & & & $(0.08)$ & $(0.08)$ & $(0.08)$ \\
\hline \multirow[t]{2}{*}{ Conventional unfriendly } & & & $0.18^{* * *}$ & $0.15^{* * *}$ & $0.16 * * *$ \\
\hline & & & $(0.02)$ & $(0.02)$ & $(0.02)$ \\
\hline \multirow[t]{2}{*}{ Healthiness } & & & & $0.34 * * *$ & $0.44 * * *$ \\
\hline & & & & $(0.05)$ & $(0.04)$ \\
\hline \multirow[t]{2}{*}{ Label trust } & & & & $0.78 * * *$ & \\
\hline & & & & $(0.09)$ & \\
\hline \multirow[t]{2}{*}{ Availability } & & & & $0.07 * * *$ & $0.06 * * *$ \\
\hline & & & & $(0.02)$ & $(0.02)$ \\
\hline \multirow[t]{2}{*}{ Constant } & $2.41 * * *$ & $2.09 * * *$ & $1.46^{* * *}$ & $0.67 * * *$ & $1.23 * * *$ \\
\hline & $(0.04)$ & $(0.14)$ & $(0.17)$ & (0.19) & $(0.18)$ \\
\hline $\mathrm{N}$ & 3,493 & 2,985 & 2,789 & 2,664 & 2,856 \\
\hline Adjusted R-square & 0.04 & 0.05 & 0.08 & 0.14 & 0.11 \\
\hline
\end{tabular}

